\title{
Concept of Ayurvedic Shodhana Process - Not Mere purification
}

\section{Kalaskar MG*}

RC Patel Institute of Pharm Education and Research, India

*Corresponding author: Mohan G Kalaskar, R C Patel Institute of Pharm Education and Research, B/15, Om Colony, Shirpur, Dhule, India, Tel: +918149448119; Email-

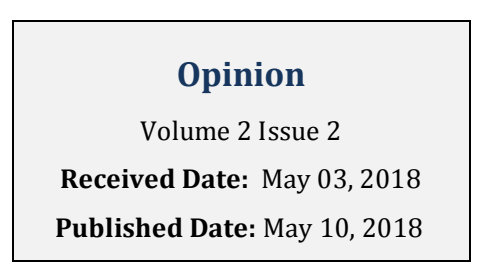

kalaskar.mohan@gmail.com

\section{Opinion}

In Ayurveda, the concept of shodhana for the potential herbs, minerals and metals was got references available since the time of Ayurvedic classics but the details about procedure could be traced only after the development of Rasashastra/ Rasachikitsa (Mineral therapy). It also mentioned that shodhana responsible for the alteration or addition of the properties of the drugs while subjected to various pharmaceutical operations and treatments. It is processes of detoxification by which not only physical and chemical blemishes and toxic materials are eliminated but to convert them to the pharmaceutically suitable forms in which these may be absorbed into the system if used internally or may be treated further. The substance which has to be purified is called as Shudhidravya/ shodhya dravya and the substance with which it is treated for purification called Shodhana dravya. Shodhana are the tools to bring poisonous medicinal plants into the mainstream and to make them more accountable.

The shodhana in modern language is purification. The purification meaning removal of unwanted material or impurity from the drug. The shodhana in Ayurveda is removal of unwanted material along with treatment of drugs with other substance (Media) which results into accumulation of these substances in the shodhit drugs, these are responsible for making the drug more effective.

\section{Shodhana}

It is a process by which unwanted impurities are separated from the substance by various pharmaceutical methods like Kshalana (Washing), Mardana (Pounding), Bhavana (Levigation), Swedana (Boiling), Bharjana
(Frying), Nirvapa (Heating \& Dipping in specified liquids), etc. with specific drugs (media) thereby minimization the toxicity of the substance and enhances the properties of the drug suitable for desired actions.

In Ayurveda, the shodhana carried out for to elimination of physical and chemical impurities, change in physicochemical properties, remove toxicity, increase the potency of the drug material, and induce desired qualities for further processing.

Shodhana process is grossly subdivided into two major categories as samanya and vishesha

\section{Samanya shodhana (General)}

It is generally applied for the drugs which are come into one category like Maharasa, Uparasa, Ratna, Dhatu.The drugs of one group having some similar types of impurities. So that with the help of Samanya shodhana general impurities can be removed. Eg Dhatu-Samanya Shodhan.

\section{Vishesh shodhana (Specific)}

It is specifically applied for the drugs which contain high concentrated chemicals. Each drug of the group may have different types of impurities. Which are vary from substances to substances \& are removed by Vishesh Shodhana.

Both the above procedures are further classified into Saagni and Niragni. 


\section{Journal of Natural \& Ayurvedic Medicine}

Saagni (with Fire): Nirvapa, Dhalana, Bharjana, Puta, Swedana, Patana

Niragni (without Fire): Bhavana, Prakshalana, Shoshana, Sinchana, Nimajjana, Gharshana

The use of specific media has its own importance. The ancient Ayurvedic scholars has very wisely used it, it is furthermore drug specific. It helps in breaking down or altering the chemical constituent that is not required. It is very interesting that specific media is used for specific substance. Various techniques along with different media are referred in Ayurvedic texts for the shodhana, knowing different nature of impurities. The media acts like a solvent to dissolve the material for easy separation from the insoluble impurities to eradicate toxic chemical substances from the drugs and also helps in physical transformation of some of metals and minerals. There are abundant examples of ancient scholars of Rasa Shastra using different media and material of different sources in the process of shodhana depending on the Drug and purpose.

\begin{tabular}{|c|c|c|c|}
\hline No & Media & Example & Utility \\
\hline 1 & Sneha Varga & Taila, Ghrita, Dugdha & Softening of Hard material 8 \\
\hline 2 & Amla Varga & Takra, Kanji, Nimbu, Amalaki & Mass breaking and dis-integration 9 \\
\hline 3 & Kshara Varga & Mutra, Kulattha Kwatha, Kadali Kanda & Makes the material soft and brittle 10 \\
\hline 4 & Katu Varga & Nirgundi, Hariraki, Bhringaraja & $\begin{array}{c}\text { Disintegration and breaking the } \\
\text { cohesion }\end{array}$ \\
\hline 5 & Tikta Varga & Vasa, Swarna Ksheeri, Shireesha & Absorption of Moisture \\
\hline 6 & Kashaya Varga & Kanchanara, Haritaki, Vibhitaki & Eliminates external impurities \\
\hline 7 & Visha Varga & Shringataka, Kalakuta, Vtsanabha, Saktuka, Peeta Visha & Removes inertia in the substance \\
\hline 8 & Vitgana / varga & Paravata, Chasha, Kapota, Kalapina, Gridhra, Kukkuta & Sarva Loha shodhana \\
\hline 9 & Mridukara Varga & Mahishasringi, Indrayava & Softening of hard metals \\
\hline 10 & Dravaka Varga & Guda, Guggulu, Gunja, Ghrita, Madhu, Tankana, & Soften and liquefies metals \\
\hline 11 & Lavana Varga & $\begin{array}{c}\text { Samudra, Saindhava, Kacha, Bida, Sauvarchala, Romaka, } \\
\text { Chullika, Audbhida Lavana }\end{array}$ & Sarvaloha Dravana and Shodhana \\
\hline
\end{tabular}

Table 1: Types of Media Used in Shodhana.

The procedure adopted for shodhana, duration and purpose are different. The process of shodhana to be adopted depends upon the material for which shodhana to be done. This depends upon the source of material, its chemical composition, impurities and its physical properties. By shodhana process many material changes are elicited both physically and chemically.

\begin{tabular}{|c|c|c|c|}
\hline No & Procedure & $\begin{array}{l}\text { Purpose } \\
\end{array}$ & Example \\
\hline 1 & Bharjana & Fry / to dehydrate - Unwanted part vaporates & Gairika Shodhana \\
\hline 2 & Bhavana & $\begin{array}{l}\text { Reduction of particle size and also transfer of impurities } \\
\text { from material to liquid media }\end{array}$ & Sasyaka Shodhana \\
\hline 3 & Dhalana & $\begin{array}{l}\text { Melting solid raw drug and dipping in cold liquid. Separation } \\
\text { of adulterants \& reducing brittleness }\end{array}$ & $\begin{array}{l}\text { Gandhaka Shodhana - Gandhak } \\
\text { in Godugdha }\end{array}$ \\
\hline 4 & Galana & $\begin{array}{l}\text { Filtration - Separation of adulterants and heterogeneous } \\
\text { substances }\end{array}$ & Gandhaka Shodhana \\
\hline 5 & Gharshana & $\begin{array}{c}\text { Brings down the toxicity and also separation of outer } \\
\text { covering }\end{array}$ & Bhallataka Shodhana \\
\hline 6 & Mardana & $\begin{array}{l}\text { Trachuration with Swarasa, Kashay, Godugdha, Gomutra - } \\
\text { Particle size of drug becomes synergistic additives which } \\
\text { causes an agonistic effect }\end{array}$ & $\begin{array}{l}\text { Jambir Swarasused to triturate } \\
\text { tamra patra. }\end{array}$ \\
\hline 7 & Murchana & Reduction in particle size & $\begin{array}{l}\text { Parada Shodhana - Parad by } \\
\text { Adrak swaras. }\end{array}$ \\
\hline
\end{tabular}




\section{Journal of Natural \& Ayurvedic Medicine}

\begin{tabular}{|c|c|c|c|}
\hline 8 & Nimjjan (dipping) & $\begin{array}{l}\text { Keeping raw drug in certain liquid for certain time. - } \\
\text { Chemical Changes from } \\
\text { higher concentration to lower concentration takes place. }\end{array}$ & $\begin{array}{l}\text { Vatsanabha Shodhana- astnabha } \\
\text { in godugdha - Gomutra }\end{array}$ \\
\hline 9 & Nirjalikarana & Evaporation of water molecules & Kankshi Shodhana \\
\hline 10 & Nirvapa / Nisheka & $\begin{array}{l}\text { Heating solid drug \& dipping into cold liquid -To brittleness } \\
\qquad \text { \& softness }\end{array}$ & $\begin{array}{c}\text { Abhraka Shodhana - Abhrak in } \\
\text { Triphala quath }\end{array}$ \\
\hline 11 & Pachana & $\begin{array}{l}\text { Shodhya Dravya Immersed in Shodhana Dravya and and } \\
\text { keeping on fire. } \\
\text { Softness occurs and Stickiness reduces due to this process. }\end{array}$ & $\begin{array}{l}\text { Guggulu Shodhana - Guggulu in } \\
\text { Gudugdha / TriphalaKwath }\end{array}$ \\
\hline 12 & Patan(To Distil) & $\begin{array}{c}\text { By giving heat to substances so that it vaporizes \& the } \\
\text { extract is collected - } \\
\text { Separation of adulterants causes purified medicine. }\end{array}$ & Extraction of Parad from Hingu \\
\hline 13 & Prakshalana & $\begin{array}{c}\text { clean or proper washing - Removal of dust \& Spurious } \\
\text { material }\end{array}$ & $\begin{array}{l}\text { Satavari roots washing with } \\
\text { water. }\end{array}$ \\
\hline 14 & Shoshan & $\begin{array}{c}\text { Drying in sunlight/moonlights - Absorption takes place at } \\
\text { tissue level }\end{array}$ & Apamary bija \\
\hline 15 & Sinchana & $\begin{array}{l}\text { Sprinkling liquid on hot drugs - To make the substance } \\
\text { brittle }\end{array}$ & Tamra Shodhana \\
\hline 16 & Swedana & $\begin{array}{l}\text { Vaporizations of raw dugs in certain liquid materials - } \\
\text { Reduction of Toxicity, Removal of impurities and to soften }\end{array}$ & $\begin{array}{l}\text { Haratala Shodhana - Hartal in } \\
\text { Kushmandswaras. }\end{array}$ \\
\hline 17 & Sthapan & $\begin{array}{c}\text { Keeping dravya in stable condition } \\
\text { Kalgunvradhi (increases quality of drug) } \\
\end{array}$ & Puran gruth, \\
\hline 18 & Vibhag & Separation of unwanted part Minimizes the Tikshanata & Rasankur in Rasun \\
\hline
\end{tabular}

Table 2: Different shodhana processes, purpose with examples.

Shodhana is the first samskara and it is necessary to understand the concept of shodhana properly. It is purification not by physical means but also by chemically. The literature published and clinical evidences of shodit dravyas confirms there is a strong rationality between the method, duration, instruments and the drugs which are being used in the process of Shodhana. The ancient Ayurvedic science recommends that these drugs should be administered in purified form. Shodhana is a prerequisite for all Rasa dravyas. Shodhana helps in sanghatabheda of a drug, removing dravya gata and aushadhagata doshas and makes it more marana upayogi and also helps in achieving guna vriddhi of the drug. Apart from removing the impurities shodhana treatments of Rasa Shastra also impregnate organic materials and their properties in the inorganic drugs/ products to facilitate their utilization by the body tissue and organs. Hence, the concept of Shodhana (processing or purification) in Rasashastra is not merely a process of purification/detoxification but also a process resorted to enhance the potency and efficacy of the drug. That's why the shodhana plays an important role in Rasashastra. 